\title{
Dutch Oceanographic Research in Indonesia in Colonial Times
}

WELL BEFORE THE political independence of the Republic of Indonesia after serasal ${ }^{128} /$, World War II, oceanographic research was carried out in the deep waters of the Indo-to nesian archipelago. The single scientific expeditions carried out using the Dutch naval vessels Siboga and Snellius show up in lists of historically important oceanographic expeditions, though their many reports are hardly read anymore except by taxonomic specialists. Oceanographers know about such expeditions and their results only if they happen to be mentioned in oceanography textbooks. For example, few textbooks mention that gravity measurements taken on board Dutch submarines contributed to the understanding of plate tectonics or that Dutch scientists at the meteorological service contributed to early studies of marine climate and surface circulation. Oceanographic research was part of the colonial policy of the Netherlands, but the initiatives for that research usually came from scientists in the Netherlands rather than the Dutch colonial government.

\section{THE EARLY DAYS}

From 1598 onward, the Dutch were present in Indonesia. They first arrived as visiting traders and inhabitants of trading posts. The Dutch soon became local sovereigns, and remained a colonial power until Indonesia became politically independent after World War II. During the first visit of the Dutch to Indonesia in 1598 , the merchant Willem Lodewijckz made extensive notes of the fishes and sea mammals that he encountered (de Groot, 1973). In 1606, eight years after their first arrival in Indonesia, the Dutch United East India Company (Vereenigde Oost-Indische Compagnie, or VOC) fitted a ship under the command of Willem Jansz to search for new lands, sea routes, and trade in the seas around New Guinea. Such exploratory cruises lasted until the VOC charter expired in 1799. The VOC was a commercial company, thus most of the data gathered during these exploratory cruises, as well as data gathered during regular trading voyages, was strategic information treated as a business secret. The VOC archives in The Hague, Jakarta, and Cape Town probably contain a treasure trove of undocumented climatic and oceanographic information from the Indonesian seas, collected during nearly two centuries of VOC voyages. 


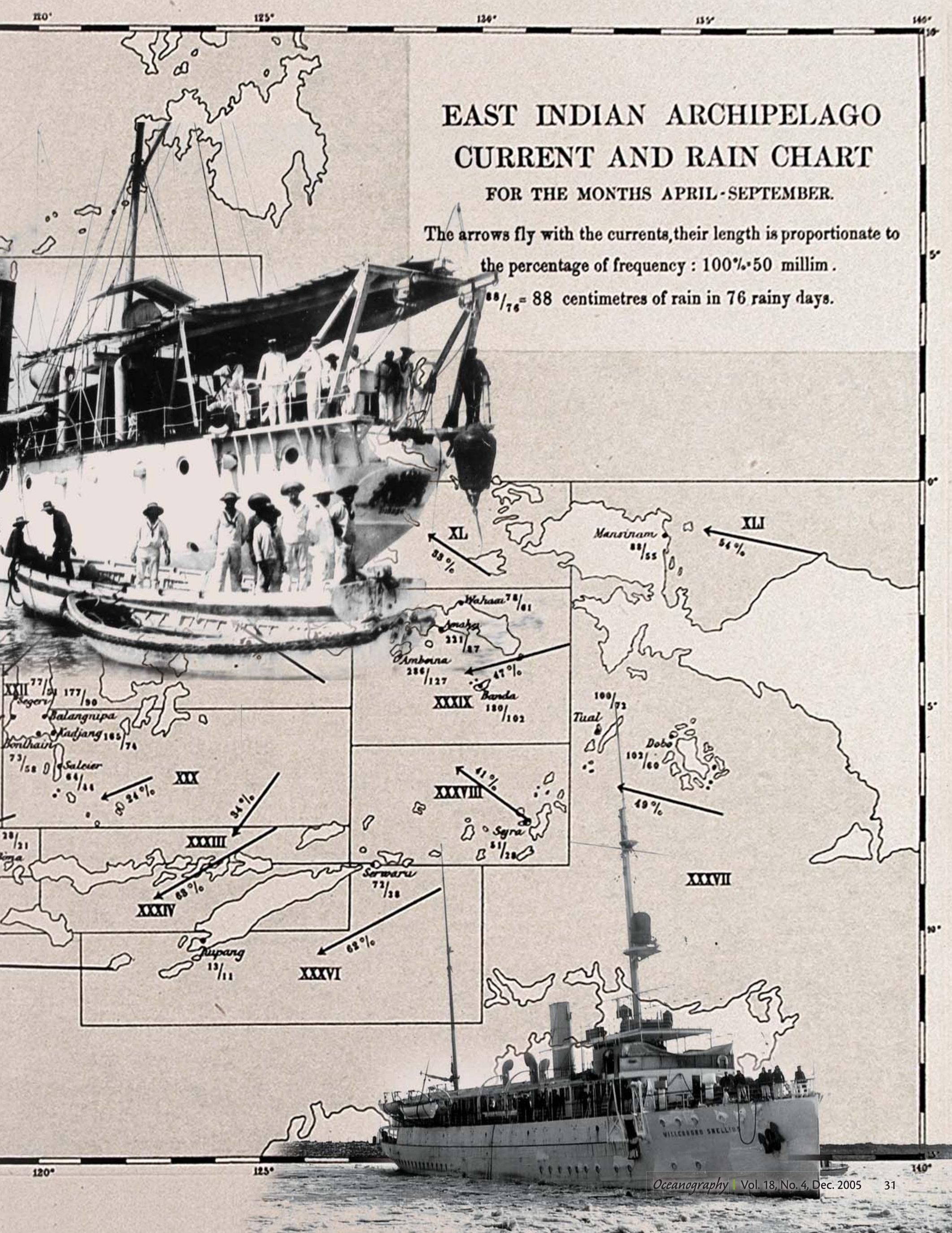


A single, but exceptional, example of early scientific research in Indonesia was the work of Rumphius, the German-born Georg Everhard Rumpf (1627-1702). He was stationed on the spice island Ambon (in the eastern part of the Indonesian archipelago) as agent for the VOC. In addition to his VOC responsibilities, Rumphius took it upon himself to study shells, crustaceans, minerals, plants, and animals. Most of his research on marine organisms was published posthumously in 1705 in the D'Amboinsche Rariteitkamer (English translation; Rhumphius, 1999). The reluctance to invest much in science remained during the later Dutch colonial rule in the nineteenth century. The colonies had to pay for themselves and to be profitable for the Netherlands, and science was not a good investment.

Following the slow establishment of a Dutch government in the East Indies after the VOC went bankrupt, and the territorial spread of its colonial power over the archipelago, a need grew for accurate hydrographic knowledge. In 1821, the Commission for the Improvement of Indian Sea Charts was founded. This commission was not able to do much, and was disbanded in 1834, only to be re-established in 1838 and disbanded again in 1867 (Backer-Dirks, 1985). Because of a tight budget, the available surveying capacities of the Dutch colonial rulers were limited. They carried out few oceanographic surveys in deep water. Dutch colonial navy was not able to perform even such basic tasks as surveying an important shipping passage like the Banka Strait (between the islands of Banka and Sumatra); it was the British, aboard the HMS Saracen, who surveyed this strait from 1859 to 1861 . This tight budget led to the peculiar situation that until the last year of the nineteenth century, nearly all deep-water research in the Netherlands East Indies was carried out by foreign ships and scientists (Table 1). In 1768 and 1770, respectively, the famous ocean explorers Louis-Antoine de Bougainville and James Cook visited the Indonesian archipelago. Between 1793 and 1840, French research dominated the Indonesian seas. After 1840, the British navy conducted the bulk of the research on the deep waters of the Netherlands East Indies, although the navies of the United States, Germany, and Austria also carried out deep-sea expeditions. Building a colonial empire was also part of the agenda for ocean research carried out by the big European countries and the United States. In 1858, the HNethMS Cachelot conducted one of the few Dutch hydrographic surveys in deep water. This ship, commanded by Lieutenant Commander Siedenburg, carried out deep soundings in the Banda Sea using hemp lines and a 60-kg cannonball as weight, hauled by hand power. During one of these soundings, a new species of sea feather (Pennatulida) was brought to the surface from a depth of about $4900 \mathrm{~m}$. It was named Crinillum Siedenburgii after the commander of the Cachelot (Harting, 1860; Kramer, 1990).

With the advance of steam power and steel wire technology, efficient sounding machines became available in the 1850s, which allowed surveys of the deep Indonesian ocean basins. In 1875, the HMS Challenger found the Banda Sea to be greater than $5000 \mathrm{~m}$ deep, and observed near-bottom temperatures of $\sim 3.3^{\circ} \mathrm{C}$, an indication that deep water of polar origin flushed the deep Banda Sea. The German ship Gazelle reported in the same year temperatures of 2.9 to $3.3^{\circ} \mathrm{C}$ between 3700 and 4300 m depth in the Banda Sea. American and British surveys in the 1880s established the existence of deep trenches, with depths over $5000 \mathrm{~m}$, in the Indian Ocean along Sumatra and Java.

\section{THE SIBOGA EXPEDITION}

In 1888 the geographer, Prof. C.M. Kan of the University of Amsterdam, pleaded publicly for the organization of an oceanographic expedition to the Indonesian seas; one year later, Professor A.A.W. Hubrecht, a zoologist of the University of Utrecht, issued a similar plea (Hubrecht, 1900; l'Honoré Naber, 1922). In 1896, during the annual meeting of the Dutch Commission for the Advancement of Scientific Research in the Dutch Colonies, Professor Hubrecht proposed the establishment of a mobile zoological station in Batavia (the present capital of Indonesia, Jakarta), roughly similar to the mobile shed that formed the first housing of the Dutch Zoological Station (presently Royal Netherlands Institute for Sea Research [or NIOZ]). This initial proposal became more ambitious when Professor Max Weber, a zoologist of the University of Amsterdam, submitted a plan for an oceanographic expedition to explore the marine fauna in the deep basins of the Indonesian archipelago; he declared his availability to lead that expedition (Pieters and Visser, 1993). (Weber was the elder brother of the famous German sociologist, also named Max Weber,

Hendrik M. van Aken (aken@nioz.nl) is Senior Scientist, Royal Netherlands Institute for Sea Research (NIOZ), Texel, The Netherlands. 
born in 1852 in Bonn to a Dutch mother and a German father.)

Weber's credentials were excellent. $\mathrm{He}$ had studied biology and medicine at the universities of Bonn and Berlin. In 1883 he became professor in zoology, comparative anatomy, and comparative physiology in Amsterdam. Prior to his appointment as professor, Weber gained experience in marine biology as member of the scientific party on a research cruise to the Barents Sea in 1881. In the year of his appointment as professor, Weber married Anne van Bosse, a wealthy widow and daughter of a cabinet minister (Kieskamp, 2004). During her short widowhood (her first husband died in 1878), she took classes in biology at the University of Amsterdam, specializing in the field of marine and freshwater algae.

The Commission accepted the proposal by Max Weber for a marine biological expedition (Weber, 1902; l'Honoré Naber, 1922). The organization of the expedition was recommended to the Society for the Advancement of Scientific Research in the Dutch Colonies. The Society proposed that the colonial government should supply a research vessel. The Society was a hands-on organization that already had organized several expeditions to the central parts of Kaliman$\tan$ (Borneo). The Society immediately began lobbying the national and colonial governments, and seeking private funding to finance the planned expedition. In May 1898, the Governor General in Batavia decided that the newly built gunboat Siboga of the colonial navy should be made available to Professor Weber (Figure 1). Professor Weber was appointed as leader of the expedition and could use the ship for the duration of the expe-

Table 1. Scientific surveys of the deep waters in the Indonesian seas from the $18^{\text {th }}$ and $19^{\text {th }}$ centuries (after L'Hornoré Naber, 1922)

\begin{tabular}{|c|c|c|c|}
\hline Leader & Ship(s) & Nationality & Years \\
\hline De Bouganville & Boudeuse and Etoile & French & 1768 \\
\hline James Cook & Endeavour & British & 1770 \\
\hline $\begin{array}{l}\text { Dentrecasteaux/ } \\
\text { d'Auribeau }\end{array}$ & Recherche and Esperance & French & $1793-1794$ \\
\hline Baudin & $\begin{array}{l}\text { Geographe and Nauraliste } \\
\text { and Casuarina }\end{array}$ & French & $1800-1804$ \\
\hline De Feycinet & Uranie and Physicienne & French & $1817-1820$ \\
\hline Duperry & Coquille & French & $1822-1825$ \\
\hline De Bouganville Jr. & Thetis and Esperance & French & $1824-1826$ \\
\hline Kolff & Dourga & Dutch & $1825-1826$ \\
\hline Dumont d'Urville & Astrolabe & French & $1826-1829$ \\
\hline Fitzroy & Adventure and Beagle & British & $1826-1836$ \\
\hline Steenboom & Triton and Iris & Dutch & 1828 \\
\hline Laplace & Favorite & French & $1830-1832$ \\
\hline Laplace & Artemise & French & $1837-1840$ \\
\hline Dumont d'Urville & Astrolabe and Zele & French & $1837-1840$ \\
\hline Belcher & Sulphur & British & $1837-1842$ \\
\hline Unknown & Samarang & British & $1843-1846$ \\
\hline von Wüllerstorf-Urbair & Novara & Austrian & 1858 \\
\hline Siedenburg & Cachelot & Dutch & 1858 \\
\hline Bullock & Serpent & British & 1863 \\
\hline Wyville Thomson & Challenger & British & 1875 \\
\hline Von Schleinitz & Gazelle & German & 1875 \\
\hline Unknown & Borneo & Dutch & 1881 \\
\hline Barker & Enterprise & American & 1883 \\
\hline Jewell & Essex & American & 1886 \\
\hline Unknown & Flying Fish & British & 1886-1887 \\
\hline Aldrich & Egeria & British & $1887-1888$ \\
\hline Unknown & Recorder & British & 1888 \\
\hline Unknown & Benkoelen & Dutch & 1889 \\
\hline Vereker & Rambler & British & 1890 \\
\hline Unknown & Banda & Dutch & 1896 \\
\hline Chun & Valdivia & German & $1898-1899$ \\
\hline Weber & Siboga & Dutch & 1899-1900 \\
\hline
\end{tabular}


dition, estimated to last about one year.

The colonial government also would pay for the required fuel (coal), ship maintenance, and the wages for the ship's commander, officers, and crew. Lieutenant-commander G.F. Tydeman was appointed as commander of the Siboga. He was a very able naval officer, with a keen interest in science. In 1894, Tydeman was seconded to the astronomical observatory of the University of Leiden to qualify in astronomy. Thereafter he became a teacher in navigation and astronomy at the Royal Institute for the Navy (naval academy) in Den Helder, The Netherlands (van Oosten, 2003).

The willingness of the colonial navy to make their gunboat Siboga available for scientific research was a result of the Dutch need to establish complete colonial rule and to show the flag over the whole archipelago at the end of the nineteenth century. During that period, new colonial states encroached towards the Dutch possessions. In 1884, Germany occupied northeastern New Guinea and the Bismarck Archipelago shortly after the British claimed the southeastern coast of New Guinea. In 1895, Japan started its advance in a southwestern direction by occupying Taiwan, and in 1898, the United States replaced Spain as colonial power in the Philippines. In response, the Dutch colonial government moved quickly to establish its military and administrative power in all corners of its Asian empire (Fasseur, 1983).

The Siboga was a gunboat of the Netherlands East Indies military navy, which was launched in April 1898 (Tydeman, 1902). The vessel was $50.6 \mathrm{~m}$ long, had two propellers, and was driven by a 1400 horsepower steam engine. Heavy scientific equipment, such as electrical and steam winches, were installed on empty gun platforms. To outfit this ship for scientific work, Weber bought different types of thermometers to measure surface and sub-surface temperatures, as well as bottles devised to collect water samples. He purchased laboratory equipment and chemicals to determine dissolved oxygen concentration. Following the advice of German and British colleagues, and after reviewing examples of the equipment used during the Challenger and Valdivia Expeditions, Weber also ordered a large variety of vertical nets, trawls, and dredges to collect plankton and larger organisms. He had large quantities of alcohol in oak casks and formaldehyde stored on the ship to preserve biological samples; zinc boxes in wooden crates would contain these samples. A Le Blanc Sounding Machine (manufactured in Paris and owned by the colonial government) and a Britishbuilt Lucas Sounding Machine (made available by the Dutch navy) were available for deep-sea soundings.

After all the equipment was stored on board, the Siboga left Amsterdam for Surabaya on December 16, 1898 (Weber, 1902). After arrival in Surabaya, final preparations were made; on March 7, 1899, in the early morning, the Siboga left port. Scientists on board were Max Weber as Expedition Leader and Chief Scientist. His wife, Anne Weber-van Bosse, participated (unofficially) in the expedition as Algologist, in charge of studying all marine flora. This participation of a female scientist was probably the world's first in oceanographic history. Dr. J. Versluys was First Assistant to Prof. Weber, and a candidate (equivalent to bachelor of science) H.F. Nierstrasz was Second Assistant. A draftsman from the botanical gardens in Bogor on Java (then named Buitenzorg), Mr. J.W. Huysman, was assigned to the expedition. Tydeman, the commander of the Siboga, was in charge of the hydrographic observations. Apart from seven officers and four corporals, who all came from the Netherlands, the crew of the Siboga consisted of 48 native Indonesian sailors, led by a mandur (chief petty officer) named Atur. These Indonesian sailors operated the winches, capstans, and sounding machines during the expedition. Although the purpose of the expedition was to study the deep Indonesian basins, a secondary goal was to research coral reefs and shallower seas. This latter objective was added on advice from Sir John Murray, who stated that during the Challenger Expedition not enough attention had been spent on life in the upper $1000 \mathrm{~m}$ of the ocean and in coastal environments (Weber-van Bosse, 1903).

During the Siboga Expedition, it became customary for Prof. Weber and Dr. Versluys to sample the reefs while $\mathrm{Mr}$. Nierstrasz stayed on board to process the samples in the laboratory. Mrs. Webervan Bosse often participated in sampling the coral reefs. When at sea, they took samples using the whole suite of nets and dredges. Before each dredge haul, the ship made a deep sounding with one of the sounding machines. The ship's scientists obtained bottom samples from these stations using sounding weights fitted with a hollow metal pipe. At many of the sounding stations they took a water sample some distance above the bottom and determined the temperature with a reversing thermometer. During the expe- 



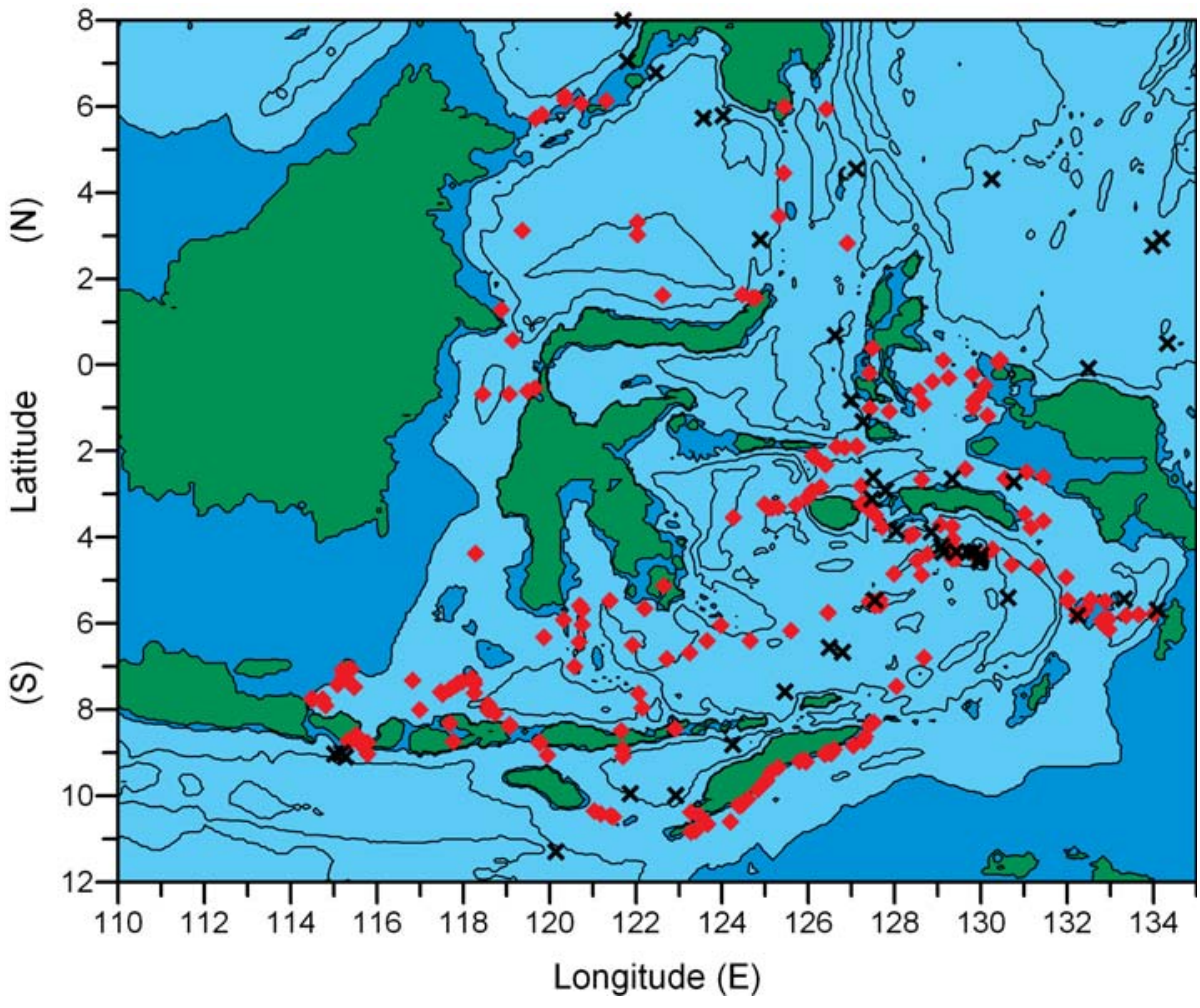

Figure 2. Positions of the hydrographic stations occupied during the Siboga Expedition (red diamonds). Black crosses show the positions of the deep soundings, carried out before the Siboga Expedition.

coccoliths, found in the sediment in large quantities, were of organic origin. Mrs. Weber-van Bosse observed with the microscope that the coccolitophoridae, which produce these calcareous discs, were algae with chlorophyll-containing chloroplasts (then named chromospheres) and cell division (Hubrecht, 1900; Weber-van Bosse, 1903).

The expedition formally ended on February 27, 1900 when the Siboga returned to the port of Surabaya. The last batch of crates with samples was sent to Amsterdam; the enormous task of analyzing and describing the large amount of zoological, botanical, and geological samples collected had to begin (Hubrecht, 1900). Although only four scien- tists carried out the sampling activities onboard the Siboga, many more were involved in analyzing the samples and specimens. Ultimately, a series of over 130 monographs on the Siboga Expedition appeared between 1901 and 1982 . zoological subjects, five with algae, two with geology, and only one, written by Tydeman, dealt with the topographic relief of the archipelago. The temperature measurements and oxygen measurements were not discussed. The publication of the series was an international effort by authors from 12 countries, including Japan, Italy, India, the United States, and Canada. As recognition for her scientific work on algae, the UniverMost of these monographs dealt with sity of Utrecht granted Mrs. Weber-van Bosse an honorary doctorate in February 1910. She was the first Dutch woman to receive such an honorary degree.

\section{HYDROGRAPHY AND MARINE GEOPHYSICS}

The development of a telegraph cable network in the archipelago has greatly contributed to our knowledge of the depths of the deep Indonesian basins, because cable layers required a much better horizontal resolution of depth soundings than supplied by the Siboga. Surveys for transoceanic telegraph cables led to the discovery of deep trenches along the Indian and Pacific rims of Indonesia. In the 1920s, it was assumed that the topography of deep trenches and basins could also be studied with gravity observations, because the density difference between the ocean water and the sea bottom would cause equipotential surfaces to deform (Vening Meinesz, 1966). The Dutch geodesist and geophysicist Prof. F.A. Vening Meinesz had developed a pendulum gravimeter with which he could determine the gravity at sea with the required accuracy of 1:250,000, provided that the ship's motion was quite limited. A submerged submarine was the ideal platform for such an instrument. In 1923, the first voyage with a gravimeter mounted on board of the outward-bound Dutch colonial submarine $K I I$ allowed gravity measurements in the seas around Indonesia. This was the first of a series of marine gravity surveys with Dutch submarines on their outward-bound trip to the Asian colonies. Often the planned routes of these voyages were specially adapted to improve the spatial coverage of the gravity measurements. All trenches around 
the Indonesian archipelago, on the Pa-

cific and Indian Ocean sides, were surveyed in this way, while special surveys were organized to fill in details. During the first of such special surveys near the Java Trench, the observed strong negative gravity anomalies pointed to a serious local shortage of mass. However, these anomalies did not coincide with the location of the trench, as was expected, but with the ridge south of the trench. For such results, the slowly emerging hypothesis of continental drift gave the right interpretation scheme. The experience, gained by these gravity measurements in the Indonesian archipelago, led to similar submarine observations in other parts of the world, and by other navies.

\section{THE EXPEDITION WITH THE} WILLEBRORD SNELLIUS

Physical oceanographic measurements during the Siboga Expedition were very limited, although Tydeman was able to derive the deep circulation of water from the Pacific Ocean (via the Banda Sea towards the Indian Ocean) from the observed deep temperatures. These results were not published in the series of Siboga publications. Tydeman reported his interpretation during a lecture that he gave in 1901 at the Navy Club in Den Helder. Over 20 years later, a printed version of his ideas was finally published (Tydeman, 1922).

Plans for the German Meteor Expedition from 1925 to 1927 in the South Atlantic inspired the hydrographer of the Dutch navy, Commander Luymes, to propose in 1925 to the Royal Netherlands Geographical Society a new expedition to the deep basins of eastern Indonesia focused on the physical oceanography and geology of the area. This expedition should also confirm that the Netherlands Indies were, "not only the best governed, but also the scientifically most developed tropical country" (Luymes, 1929). However, scientists from the Polytechnic College in Bandung (founded in 1920) were completely ignored in the planning and execution of the expedition. A committee was formed in the Netherlands to prepare an extensive research plan for the archipelago. Professor Max Weber and (then) Vice-Admiral Tydeman were members of this committee. Lobbying and fundraising lasted until 1927 when the colonial government agreed to make a new ship available and to pay for the crew, fuel, food, and other necessities. But first, the hydrographic survey ship Willebrord Snellius had to be built. Upon completion, the ship was launched in November 1928; sea trials took place in February 1929 (Figure 3).

The focus of the Snellius Expedition was the physical and chemical oceanography of Indonesia's deep basins and the geology of its coral reefs, with additional biological research on algae and animals living on the reefs. Because of the lack of academically trained oceanographers, Mr. P.M. van Riel, a retired naval officer who was head of the department of oceanography and maritime meteorology of the Royal Netherlands Meteorological Institute (KNMI), was appointed as expedition leader. Oceanography at KNMI was limited to the study of waves and surface currents in support of ocean navigation. The other oceanographic vacancies were filled in by hiring the physicist, Dr. Hamaker, and the chemists, Dr. Boelman and Dr. Hardon, but only for the duration of the expedition. The biologist, Prof. Boschma from Utrecht University, and the geologist, Dr. Kuenen from the University of Groningen, completed the scientific crew. Because of the wish of van Riel to bring his wife, Mrs. van Riel-Verloop, with him during the expedition, she was appointed secretary and chemical analyst. It was, however, expected that so many water samples had to be processed that the scientists and Mrs. van Riel would need further analytical support. Four naval seamen, who had volunteered for the expedition, were trained as analysts at Utrecht University and at the Zoological Station in Den Helder for determination of salinity and oxygen content by titration.

In March 1929, the Snellius left the port of Den Helder and arrived in Surabaya at the end of May. During the outward-bound voyage, the ship's scientists and crew tested the equipment. The ship had been fitted with two different echo-sounder systems and a Lucas Sounding Machine. With the aid of this wireline sounding machine, scientists took small bottom cores with a mean length of about $40 \mathrm{~cm}$ using Sigsbee or Meteor samplers. To obtain longer cores, the scientists constructed a four-meterlong Ekman corer. This sampler was not lowered with the sounding machine, but with the hydrographic winch, which was fitted with a $4 \mathrm{~mm}$ steel wire. The longest sample taken with this corer was $210-\mathrm{cm}$ long. To obtain the hydrographic series observations, the scientists used the hydrographic winch with Nansen samplers fitted with reversing thermometer. Seasurface temperature was continuously recorded with an electric thermograph mounted in the hull of the ship. Because 
Figure 3. The naval survey ship Willebrord Snellius, stuck in sea ice during its sea trials in February 1929. A few weeks later it was on its way to Surabaya for the start of the Snellius Expedition, which lasted nearly 16 months. () Instituut voor Maritieme Historie, The Hague.

the ship was fitted with a deep-sea anchor, it could remain stationary for repeated hydrographic observations and for current measurements. For biological sampling, some trawl nets and a bottom dredge were available, while vertical nets could be used for plankton sampling. Additionally, the scientific party installed a pump system with a gauze filter to collect plankton from the surface layer.

In Surabaya, 67 Indonesian sailors replaced part of the European crew from the outward-bound voyage. Two Indonesian technical specialists, Kartodihardjo and Erie, came on board to assist with the geological and biological sampling. On July 27, 1929, the Snellius left port for the first leg of the expedition. Following the example set by the Meteor in the South Atlantic, van Riel organized his observations along more or less straight sections through the main basins (Figure 4). Until November 15, 1930 the Snellius cruised the waters of the archipelago, interrupted by only two visits to Surabaya for maintenance and cleaning of the hull. During the expedition, a total of 374 stations were occupied. At most of these stations, hydrographic measurements were taken, often with three or four casts.
Over 500 bottom samples were collected. Shore parties were organized to collect geological and biological samples. The echosounder was nearly continuously operational during the voyage. These bathymetric data led to a staggering improvement in the knowledge of the deep undersea topography of the Indonesian archipelago. The Siboga Expedition returned with 238 deep soundings as compared to the Snellius Expedition, which brought back more than 33,000 echo soundings that greatly expanded the hydrographic data archives.

After the end of the expedition, the 
appointments of the chemists and physicists terminated, and they had to search for another occupation. These scientists lost the opportunity to spend much time on the collected oceanographic data. Mr. van Riel went back to his department at the KNMI, becoming involved again in his administrative duties as department head, not the ideal position for scientific research. Boschma and Kuenen, however, went back to their positions at their universities. They came back to their scientific communities loaded with biological and geological samples, respectively, and scientific ideas. It was possible for them to find interested students and colleagues to work on their samples. Although the focus of the Snellius Expedition was the study of ocean circulation in the deep basins, the discrepancy in manpower and opportunity to analyze data-with the oceanography on one side, and the academic geology and biology on the other side—greatly delayed oceanographic research. Only when he became director of the KNMI branch department in Amsterdam in the second half of the 1930s, van Riel got more opportunities to work on his oceanographic data. The quality of the hydrographic data turned out to be very good. Sverdrup et al. (1942) considered the bathymetric charts produced by van Riel (1934) to be excellent. In their classic textbook, Sverdrup et al. reproduced data and figures on the bathymetry, internal waves, and ocean circulation based on the work by van Riel and his team. It wasn't until the end of the 1950s, shortly after van Riel's death, before Henk Postma from the NIOZ published the last two volumes of the 23-volume series of Snellius reports. These two volumes were on the chemistry, water masses, and current structure of the East Indonesian deep basins. The geologists and biologists who worked on the samples collected by Kuenen and Boschma published over 35 papers in other publication series or in scientific journals. Still, in 1978, a paper appeared on the foraminifera of the Snellius Expedition, using data collected 48 years earlier.

\section{OPERATIONAL \\ OCEANOGRAPHY}

Knowledge of winds, currents, and tides in a marine region like the Indonesian archipelago was of prime importance for shipping activities in the age of sail. When data became available from the East Indies, responsible government agencies were eager to publish them. The study of the climatology of the ocean surface and the overlying atmosphere does not depend on spectacular oceanographic expeditions, but more on hydrographic and meteorological data collected routinely over long periods. Already in 1861, KNMI published monthly seasurface temperature distributions in the Indian Ocean, including the ocean south of Java and west of Sumatra. These data were based on observations by trading

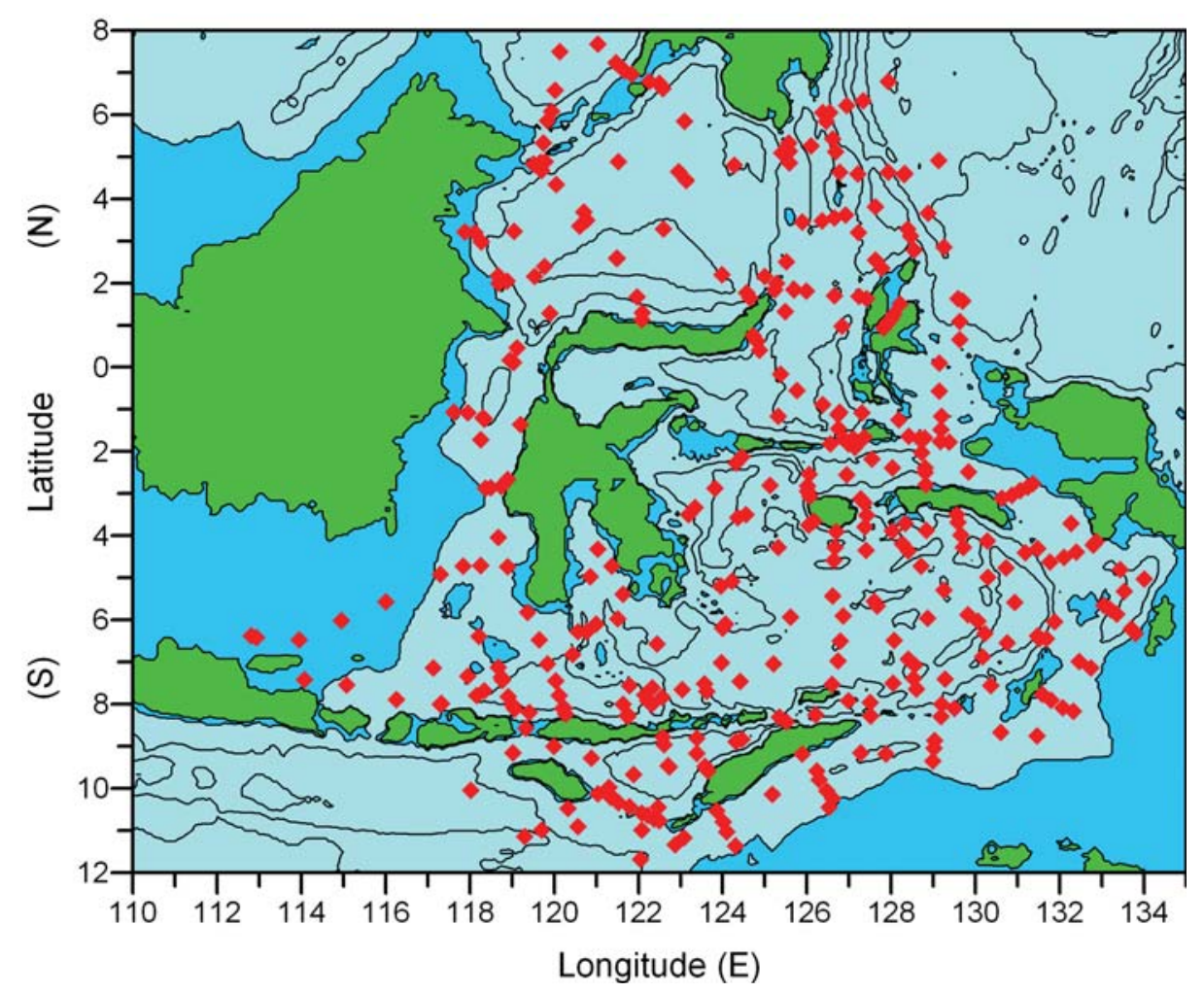

Figure 4. Positions of the hydrographic stations, occupied during the Snellius Expedition. Between these stations, the sea-water temperature was monitored continuously with an electric sensor, mounted on the hull, while the water depth was recorded with an echo sounder. In addition to the hydrographic program, bottom samples were collected, coral reefs were visited with boat parties to collect biological and geological samples, and the geologist of the expedition, Dr. Kuenen, did additional research on some islands. 

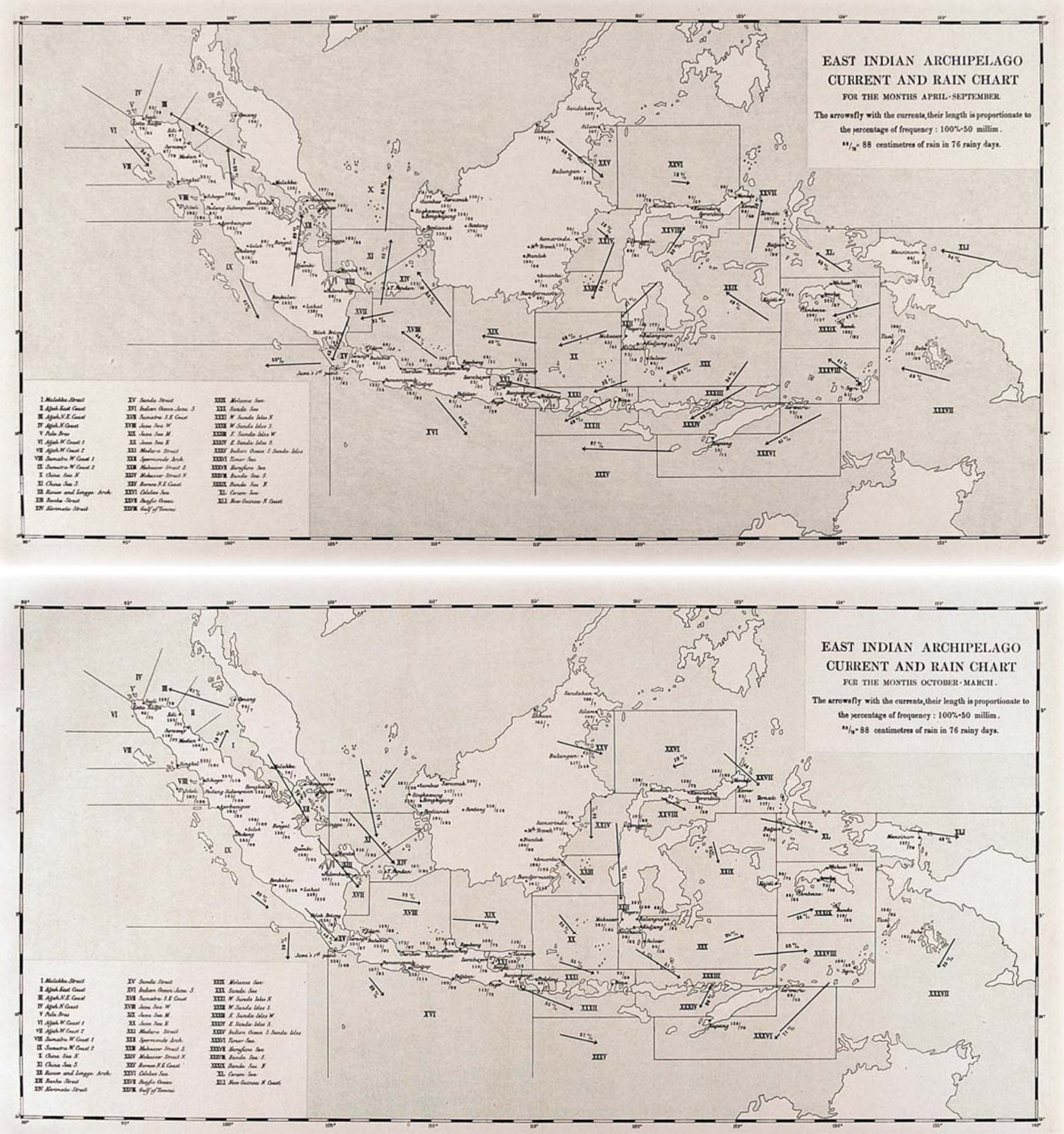

Figure 5. Maps with average surface current vectors for two different six-month seasonal periods, April to September (upper panel) and October to March (lower panel), published by van der Stok (1897). These maps were based on navigational data from the logbooks of Dutch naval vessels from 1815 to 1890 (dead reckoning and astronomical navigation). 
vessels. In the Indonesian archipelago, the main source of routinely collected marine meteorological data was the logbooks of the Dutch naval vessels that had roamed the archipelago since 1814 . The director of the Royal Magnetic and Meteorological Observatory in Batavia, the physicist Dr. van der Stok, ordered the logbooks back to Batavia from the archives in the Netherlands in order to analyze the weather and drift observations as a contribution to the physical geography of the Indies. Logbooks of all navy ships that were operational in the archipelago from 1814 until 1890 were made available to van der Stok. These analyses led to the publication of his atlas Wind and Weather, Currents, Tides and Tidal Streams in the East Indian Archipelago by the Government Printing Office of Batavia (van der Stok, 1897). From the calculated ships drift, van der Stok had derived the mean surface current per monsoon season (speed and direction) for 36 sea regions in the archipelago. These data showed the persistency of the southward throughflow in Makassar Strait, while in most other regions the surface currents reversed with the change of the monsoon (Figure 5). Van der Stok also reported the harmonic analysis of the vertical tide and tidal current at 80 positions in Indonesia, based on data records of one year or longer.

\section{CONCLUSIONS}

For Dutch marine research in colonial Indonesia, the lack of government initiative and funding was a permanently recurring feature. The colonial government mainly spent money that it had to anyway - for example, the exploitation costs of the Siboga and Willebrord Snel- lius or the outward-bound voyages of the submarines used by Vening Meinesz, mainly for reasons of colonial policy and national pride. In some way the expeditions can be considered as "gunboat science.” Initiatives for ocean research came from learned societies and private persons in the Netherlands; private money was needed to pay for personnel and scientific instrumentation. Despite limited governmental support, important results were obtained, thanks to the efforts and initiatives of capable and hard-working people. The series of publications generated by the Siboga Expedition led by Prof. and Mrs. Weber remain monument to science. The gravity measurements by Vening Meinesz contributed to the foundations of plate tectonics. And even Commander van Riel, permanently plagued by lack of time and staff after the end of the Snellius Expedition, set an example of highquality hydrographic observations.

\section{ACKNOWLEDGEMENTS}

I dedicate this paper to the late Prof. Henk Postma, who introduced me to the oceanography of Indonesia. My colleagues Johan van Bennekom and Gerhard Cadee supplied me with useful suggestions and comments.

\section{REFERENCES}

Backer-Dirks, F.C. 1985. De gouvernementsmarine, vol. 1. De Boer Maritiem, Weesp, 336 pp.

De Groot, S.J. 1973. Het zeevisserij-onderzoek in Nederlands-Indië. Vereniging Voor Zeegeschiedenis [Seminar in Maritime and Regional Studies; Proceedings Naval History Symposium 1973[ Mededelingen van de Nederlandse Vereniging voor Zeegeschiedenis 26:43-54, 117-121.

Fasseur, C. 1983. Nederland en Nederlands-Indië, 1795-1914. Algemene Geschiedenis der Nederlanden 11:346-379. Fibula-van Dishoeck, Weesp.

Harting, P. 1860. Resultaten van het onderzoek omtrent de soorten van grond, afkomstig uit de Banda zee, en omtrent enige andere voorwerpen. P. 168 in
Onderzoekingen met den zeethermometer. Koninklijk Nederlands Meteorologisch Instituut, Utrecht. Hubrecht, A.A.W. 1900. The cruise and deep-sea exploration of the Siboga in the Indian Archipelago. Nature 62:327-328.

Kieskamp, A. 2004. Bosse, Anne Antoinette van (18521942). In: Biografisch Woordenboek van Nederland. [Online] Available at: http://www.inghist.nl/ Onderzoek/Projecten/BWN/lemmata/bwn6/bosse.

Kramer, K.J.M. 1990. Een Nederlands bewijs voor leven in de diepzee. Tijdschrift voor de Geschiedenis van de Geneeskunde, Natuurwetenschappen, Wiskunde en Techniek 13:83-87

L'Honoré Naber, S.P. 1922. Historisch overzicht van het onderzoek. Pp. 1-54 in De Zeeën van Nederlandsch Oost-Indië. E.J. Brill, Leiden, The Netherlands.

Luymes, J. 1929. Korte schets van de ontwikkeling der oceanographie en de expeditie van H.M. Willebrord Snellius. Tijdschrift van het Koninklijk Nederlands Aardrijkskundig Genootschap XLVI (2-reeks):337358.

Pieters, F.F.J.M., and J. de Visser. 1993. The scientific career of the zoologist Max Wilhelm Carl Weber (1852-1937). Bijdragen tot de Dierkunde [Contributions to Zoology] 62:193-214.

Rumphius, G.E. 1999. The Ambonese Curiosity Cabinet. Yale University Press, New Haven and London, (English translation of the 1705 original), $567 \mathrm{pp}$.

Sverdrup, H.U., M.W. Johnson, and R.H. Fleming. 1942. The Oceans: Their Physics, Chemistry, and General Biology. Prentice-Hall, Englewood Cliffs, NJ, 1087 pp.

Tydeman, G.F. 1902. Description of the ship and appliances used for scientific exploration. Siboga Expedition, Monograph II, E.J. Brill, Leiden, The Netherlands, $32 \mathrm{pp}$.

Tydeman, G.F. 1903. Hydrographic results of the Siboga Expedition. Siboga Expedition, Monograph. III, E.J. Brill. Leiden, The Netherlands, 78 pp.

Tydeman, G.F. 1922. Opmerkingen betreffende de temperatuur van het zeewater. Pp. 102-124 in De Zeeën van Nederlandsch Oost-Indië. E.J. Brill, Leiden, The Netherlands.

van der Stok, J.P. 1897. Wind and weather, currents, tides and tidal streams in the East Indian archipelago. Government Printing Office, Batavia, 209 pp.

van Oosten, F.C. 2003. 'Tydeman, Gustaaf Frederik (1858-1939)', in Biografisch Woordenboek van Nederland. [Online] Available at: http://www. inghist.nl/Onderzoek/Projecten/BWN/lemmata/ bwnl/tydeman.

Van Riel, P.M. 1934. The bottom configuration in relation to the flow of the bottom water. Snellius Expedition, Vol. II, Part 2, Chapter II. E.J. Brill, Leiden, The Netherlands.

Vening Meinesz, F.A. 1966. Zwaartekracht expedities met Nederlandse onderzeeboten 1923-1954. Pp. 315-331 in De Nederlandse onderzeedienst 1906-1966. Zuidhollandse Uitgevers Maatschappij, Den Haag.

Weber, M. 1902. Introduction et description de l'expedition. Siboga Expedition, Monograph I. E.J. Brill, Leiden, The Netherlands, 159 pp.

Weber-van Bosse, A. 1903. Een jaar aan boord H.M. Siboga. E.J. Brill, Leiden, The Netherlands, 335 pp. 